\title{
Effect of Work Discipline and Compensation on the Performance of Employees of Subang District Trade and Industrial Cooperative Office
}

\author{
Ai Juheti ${ }^{1}$, Eman Sulaeman ${ }^{2}$ \\ 1,2Universitas Singaperbangsa, Karawang \\ JI. HS. Ronggo Waluyo, Telukjambe Timur, Karawang, Jawa Barat \\ e-mail: 1610631020024@student.unsika.ac.id ${ }^{1}$, eman.sulaeman@staff.unsika.ac.id²
}

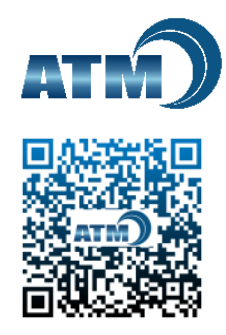

Author Notification

Final Revised

3 March 2021

Published

7 July 2021

To cite this document :

Juheti, A., \& Sulaeman, E. (2021). Effect of Work Discipline and Compensation on the Performance of Employees of Subang District Trade and Industrial Cooperative Office. Aptisi Transactions on Management (ATM), 5(2), 128-136.

DOI :

https://doi.org/10.33050/atm.v5i2.1447

Abstract
During the 2019-2024 government, President Joko Widodo made human resource development the focus of his second term government. So that the government continues to optimize the bureaucratic performance of the state civil apparatus both at the center and the region. One of the local government agencies, especially in Subang Regency, which is required to optimize bureaucratic performance is the Subang Regency Trade and Industry MSME Cooperative Office. This study uses descriptive and verification research method with quantitative approach. The population is employees of the Cooperative Office of MSME Trade and Industry Subang Regency. Sampled as many as 98 employees sample technique using the method of probability sampling a type of simple random sampling. Data collections techniques are conducted by observation, interviews and questionnaires. The results showed that partially work discipline affected employee performance by $23.4 \%$. Compensation has an effect of employee performance by $14.6 \%$. Furthermore, simultaneously work discipline and compensation have an effect on $38 \%$ of employee performance.

Keywords: Work Discipline, Compensation, Employee Performance

\section{Introduction}

Today, modern organizations are beginning to realize that the role of man is central and strategic to achieve the success of the vision and mission of the organization. Human resources can color the dynamics of organizational life, create rules and policies, design strategic systems, and have an important role in setting the direction of the organization. So strategic is the role of human resources, so that governance is needed that aims to maximize, explore the potential, and ultimately make human resources a reliable weapon for the growth and existence of the organization. The participation and contribution of human resources in playing these functions and abilities will directly affect the performance of the organization [1]. "Good performance is optimal performance, it is said to be optimal performance that meets organizational standards and supports the achievement of organizational goals. Organizations are said to be good organizations that always improve their human resources, because it is the key to improving the performance of the organization" [2].

Performance issues are an important factor for the current Indonesian government. As affirmed by President Joko Widodo has been determined to make the development of human resources as the focus of the government of the second period. The extension of several programs not only focuses on how the government is able to create quality human resources, but also makes it a capital to deal with changes colored by the rapid development of information technology. The determination of human resource development is affirmed in the theme carried out on the 74th anniversary of the Republic of Indonesia, namely "Indonesia Excels". Human resource development is the main goal of Indonesia in the future. In order to support the 
achievement of these objectives, one of them is the government continues to strive in optimizing bureaucratic performance by improving the capabilities and structuring the state civil apparatus both in the center and the region in order to be able to carry out the duties of government and development charged to him properly and correctly in accordance with applicable regulations. In this case the emphasis in the development of human resources is against the civil apparatus of the state, because they will be the motor of Indonesia's progress in the future [3].

The State Civil Apparatus in question is a civil servant. Where the civil servant consists of several elements, one of them is a civil servant. As stated in Law Number 43 of 1999 concerning Amendments to Law Number 8 of 1974 concerning personnel matters, Chapter II Article 2 paragraph (1), states that Civil Servants consist of: 1. Civil Servants; 2. Indonesian National Army; 3. State Police of the Republic of Indonesia [4].

Subang District government agencies are required to participate in supporting the success of government programs, in creating quality human resources, one of which is the Subang District Trade and Industrial Cooperative Office. Based on Subang Regent Regulation No. 57 of 2016 concerning The Main Duties, Functions and Working Procedures of the Subang District Trade and Industrial Cooperative Office, Chapter II Article 2: The Office has the main task of helping the Regent carry out government affairs in the field of Subang District Trade and Industrial Cooperative Office. Regency which becomes the regional authority and auxiliary duties given to the District Government [5], has the goal of Healthy Cooperatives, MSMEs Increase and Realize Independent Small and Medium Industries, Quality Trade, Decent Traditional Markets with Gotong Royong Based.

Success in achieving organizational goals is influenced by the subsidiary and the performance of employees. Any employee who performs highly and well according to the rules can contribute to achieving the goals and goals set by the organization [6]. So that all parties in the Cooperative Office of MSMEs Trade and Industry must be involved in creating a good performance. However, at this time, the performance of employees in the Subang District Trade and Industrial Cooperative Office can not be said either. This can be seen from the performance achievements of government agencies of the Subang District Trade and Industrial Cooperative Office. In accordance with the Decree of the Head of the Office of Cooperatives, MSMEs, Trade and Industry Subang District Number: 050/1249/ Planning on Key Performance Indicators (IKU) of the Office of Cooperatives, MSMEs, Trade and Industry Subang district year 2018-2023 [7]. More information as follows:

Table 1

Realization of Achievement of Key Performance Indicators (KPI) of the Subang District Trade and Industrial Cooperative Office in 2020

\begin{tabular}{|c|c|c|c|c|c|}
\hline No & $\begin{array}{l}\text { Performance } \\
\text { Indicators }\end{array}$ & Target & Realization & $\begin{array}{r}\text { Performance } \\
\text { Achievements }\end{array}$ & Assessment \\
\hline 1 & $\begin{array}{l}\text { AKIP Evaluation } \\
\text { Value }\end{array}$ & $\mathrm{BB}(71,00)$ & $\mathrm{n} / \mathrm{a}$ & - & - \\
\hline 2 & $\begin{array}{l}\text { Community } \\
\text { Satisfaction Index } \\
\text { Value }\end{array}$ & B & B & $\mathrm{B}(82,36)$ & Reached \\
\hline 3 & $\begin{array}{l}\text { Percentage Increase } \\
\text { in Remaining } \\
\text { Business Results }\end{array}$ & $1 \%$ & $1,6 \%$ & $160 \%$ & Reached \\
\hline 4 & $\begin{array}{l}\text { Number of Qualified } \\
\text { Cooperatives }\end{array}$ & $\begin{array}{c}700 \\
\text { Cooperative }\end{array}$ & $\begin{array}{c}845 \\
\text { Cooperative }\end{array}$ & $120 \%$ & Reached \\
\hline 5 & $\begin{array}{l}\text { Percentage Increase } \\
\text { in The Number of } \\
\text { MSMEs }\end{array}$ & $0,8 \%$ & $0 \%$ & $0 \%$ & Not Reached \\
\hline 6 & $\begin{array}{l}\text { Percentage Increase } \\
\text { in MSME Turnover }\end{array}$ & $0,92 \%$ & $-50 \%$ & $0 \%$ & Not Reached \\
\hline 7 & $\begin{array}{l}\text { Number of Trade } \\
\text { Sector PDRB }\end{array}$ & $\begin{array}{c}\mathrm{Rp} \\
\text { 5.193.133,44 } \\
\text { (Million) } \\
\end{array}$ & $\begin{array}{c}\mathrm{Rp} \\
5.775 .265,3 \\
\text { (Million) }\end{array}$ & $112 \%$ & Reached \\
\hline
\end{tabular}




\begin{tabular}{|c|l|c|c|c|c|}
\hline 8 & Export Value & $\begin{array}{c}\mathrm{Rp} \\
5.211 .759,74 \\
\text { (Million) }\end{array}$ & $\begin{array}{c}\mathrm{Rp} \\
\begin{array}{c}3.630 .659,12 \\
\text { (Million) }\end{array}\end{array}$ & $69 \%$ & Not Reached \\
\hline 9 & $\begin{array}{l}\text { Percentage Increase } \\
\text { in IKM Turnover }\end{array}$ & $1,25 \%$ & $0,34 \%$ & $27 \%$ & Not Reached \\
\hline 10 & $\begin{array}{l}\text { Percentage Increase } \\
\text { in } \\
\text { The Number of IKM }\end{array}$ & $0,2 \%$ & $0,2 \%$ & $100 \%$ & Reached \\
\hline
\end{tabular}

Description: n/a Data Not Yet Available

Source: Government Agency Performance Report year 2020

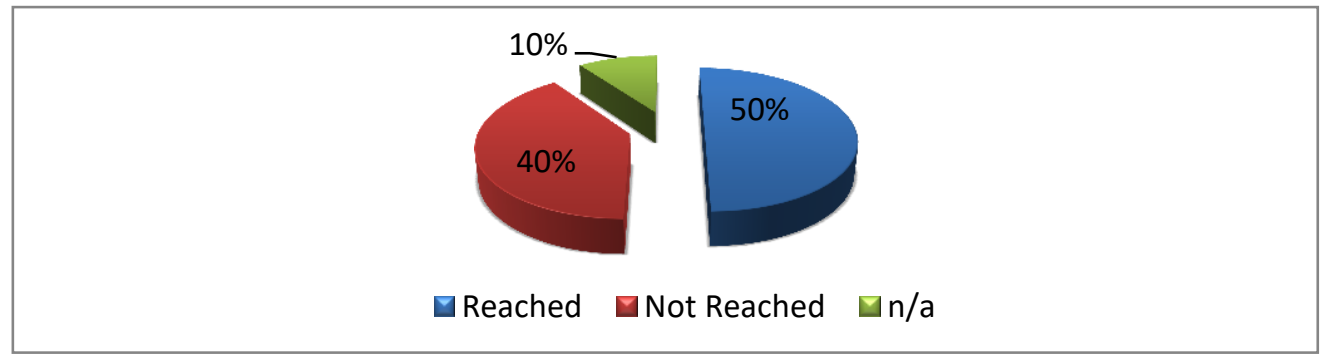

\section{Figure 1 \\ Achieving the Target Target of the Subang District Trade and Industrial Cooperative Office Source: Government Agency Performance Report year 2020}

Based on table 1 shows that there are performance targets that are not achieved including the increase in the number of MSMEs, the increase in the turnover of MSMEs, the value of exports and the increase in turnover of Small and Medium Industries (SMEs). Furthermore, based on figure 1 the performance target is not achieved which is $40 \%$. This shows that the performance of employee's agency cooperatives, MSMEs, Trade and Industry Subang district has not been optimal. In other words, employees have not been able to maximize performance in accordance with what has been planned and it is a shared responsibility to be achieved. "An employee who has high performance and good can support the achievement of goals and objectives that have been set by the organization. An employee who has high performance and good can support the achievement of goals and objectives set by the organization. Employees can work well when they have high performance so as to produce good work as well" (Hirma, 2005 ) in [8]. With the high performance of employees, it is expected that the objectives of the organization can be achieved.

Based on Government Regulation Number 30 of 2019 on the Performance Assessment of Civil Servants, Chapter I Article 1: Civil Servant Performance is the work accomplished by every civil servant in the organization / unit in accordance with SKP and the behavior of the work. Employee Performance Goals hereinafter abbreviated as SKP are work plans and targets that will be achieved by a civil servant that must be achieved every year. Work behavior is any behavior of attitude or action undertaken by civil servants or not to do something that should be done in accordance with the provisions of the legislation [9]. According to Indra Bastia, "Performance is the result of achieving levels of activities or program done in achieving the objectives of the organization, vision and mission goals contained in the formulation of an organizations strategic scheme [10]. An employee is basically in carrying out the task is expected to show the best performance, in addition to the performance shown by an employee is certainly influenced by various factors that are important means the improvement of work results into the objectives of the organization in which the employee works [11].

Next there is a recapitulation of data showing the achievement of the work attendance of employees of the Subang District Trade and Industrial Cooperative Office for the month of December 2019 and January 2020 as data for variable work disciplines, as follows:

Table 2

Effect of Work Discipline and Compensation on the Performance of Employees of Subang District Trade and Industrial Cooperative Office (Ai Juheti) 
Recapitulation of The Work Presence of the Subang District Trade and Industrial Cooperative Office December 2019

\begin{tabular}{|c|c|c|c|}
\hline \multirow{2}{*}{ No } & \multirow{2}{*}{ Number of Employees } & \multicolumn{2}{|c|}{ Work Presence } \\
\cline { 3 - 4 } & 123 & Target & Realization \\
\hline 1 & 1 & $100 \%$ & $100 \%$ \\
\hline 2 & 1 & $100 \%$ & $100 \%$ \\
\hline 3 & 1 & $100 \%$ & $100 \%$ \\
\hline 4 & 4 & $100 \%$ & $100 \%$ \\
\hline 5 & \multicolumn{2}{|c|}{$100 \%$} & $0 \%$ \\
\hline \multicolumn{2}{|c|}{130 Employees } \\
\hline
\end{tabular}

Source: General and Staffing Sub Division of MSMEs Cooperative Office of Trade and Industry Subang Regency, 2020 (processed)

Based on table 2 above, it can be explained that the presence of work in the Office of MSMEs Cooperatives trade and industry Subang district in 2019 there are 126 employees who achieved the target of work attendance of $100 \%$ then as many as 4 employees did not reach the attendance target with the achievement of $0 \%$. A percentage of $0 \%$ in achieving the target of work attendance means not fulfilling its responsibilities, namely not being disciplined in work and not being able to meet its work targets. Here's the work attendance data for January 2020:

Table 3

Recapitulation of The Work Presence of the Subang District Trade and Industrial Cooperative Office December 2019

\begin{tabular}{|c|c|c|c|}
\hline \multirow{2}{*}{ No } & \multirow{2}{*}{ Number of Employees } & \multicolumn{2}{|c|}{ Work Presence } \\
\cline { 2 - 4 } & \multicolumn{1}{|c|}{121} & Target & Realization \\
\hline 1 & 3 & $100 \%$ & $100 \%$ \\
\hline 2 & 2 & $100 \%$ & $91 \%$ \\
\hline 3 & 4 & $100 \%$ & $89 \%$ \\
\hline 4 & \multicolumn{2}{|c|}{$100 \%$} & $0 \%$ \\
\hline \multicolumn{2}{|c|}{} & \multicolumn{2}{|c|}{ Total Employees }
\end{tabular}

Source: General and Staffing Sub Division of MSMEs Cooperative Office of Trade and Industry Subang Regency, 2020 (processed)

Can see on table 3 , it can be seen that there are 121 employees who reach the target of $100 \%$. Furthermore, there were 9 employees who did not reach the target. From the data in December 2019 in table 2 and the data in January 2020 in table 3 there are still employees not reaching the target of work attendance. In other words, the presence of employees of the Subang District Trade and Industrial Cooperative Office has not been good.

Based on Government Regulation of the Republic of Indonesia Number 53 of 2010 concerning Discipline of Civil Servants, Chapter I Article 1: Discipline of Civil Servants is the ability of Civil Servants to comply with obligations and avoid restrictions specified in the laws and/or regulations of the ministry that if not obeyed or violated are punishable by discipline [12]. "Work discipline is a discipline or regulation created by the management of an organization, authorized by the board of commissioners or leaders, agreed by the next employee of the people connected in the organization is subject to the existing discipline with pleasure, so it is created and formed through the process of a series of behaviors that demonstrate the virtues of obedience and obedience, and order" [13]. Discipline includes the most important operative functions of human resources. The better the employee discipline, the higher the performance it achieves. Whereas without good discipline, it is difficult to achieve optimum performance. Therefore, employee performance can be improved by improving work discipline, because wellmanaged work discipline will have an impact on compliance with organizational regulations aimed at improving performance [14]. Discipline of employees in an agency or company plays an important role in addition to creating quality human resources can also develop agencies or companies [15].

"Compensation is the income of an employee in working in return for services provided by the company with the aim of providing stimulation and motivation to employees or workers to improve work performance" [16]. Compensation given to employees has a profound effect on job 
satisfaction and work motivation and results. Organizations or institutions in determining wage levels that consider normal living standards, will allow employees to work with full motivation. This is because the work motivation of employees is influenced by the fulfillment of the minimum needs of employees and their families. Compensation in an organization must be prepared in a structured and professional management concept. This is done so that employees get fair and appropriate compensation, so that employees can be encouraged to perform to the maximum [17]. Proper compensation and in accordance with the skills, abilities, educational background, and ethics of an employee is useful to increase employee awareness of their work responsibilities [18].

Good work discipline and appropriate compensation will provide good performance for the organization. Research shows that partial and simultaneous work discipline and compensation affect on employee performance. Similarities with previous research are variables of work discipline, compensation and employee performance. differences with previous research is the place of research and the time of research.

Furthermore, the author's interest in the issue of work discipline and compensation that affects employee performance problems that occur in the Office of Cooperative Trade and Industry Subang Regency raises the desire to conduct research and review the problems that occur by giving the title of the research "Effect of Work Discipline and Compensation on The Performance of Employees of the Office of Trade and Industry Cooperative Subang Regency". The purpose of this study is to find out how much correlation between work discipline and compensation. Next to know how big the partially influence and the influence is simultaneously of work discipline and compensation on employee performance.

\section{Research Method}

In conducting the preparation of this research there are several things that must be considered, including what methods are used to solve problems in this study. The method used is descriptive and verification research method. The population is all employees who work in the Office of UMKM Cooperative Trade and Industry Subang Regency which is as many as 130 employees. The sample was taken using slovin formula with a $5 \%$ error rate that is as many as 98 employees sample technique using the method of probability sampling a type of simple random sampling. Data collection techniques are conducted by observation, interview and questionnaire. The data source uses primary data that is data obtained directly by researchers through questionnaires distributed to 98 employees conducted on May 6 - 10, 2020. Data analysis techniques using scale range, correlation analysis and path analysis.

\section{Literature Review}

Previous research is very important as a basis or reference for the preparation of this research. Namely in the form of theories or findings through the results of various studies that have been conducted by other parties that can be used (relevant) as input and study material related to the research theme. The following are previous studies used in this study:

1) Previous research obtained in the journal Jeli Nata Liyas and Reza Primadi (2017) with the title of research "The Influence of Work Discipline on Employee Performance at The People's Credit Bank". From the results of his research explained that discipline has a significant influence on employee performance. It means that the better the work discipline applied to employees, the better the employee's performance. Similarly, the worse the work discipline applied to employees, the worse the employee's performance [19].

2) Previous research obtained in the journal Rima Alhalimah Hajrina, lis Mariam and Menik Wijiyanti (2016). With the title of the study "The Influence of Work Discipline on The Performance of Employees Marketing Section at Millennium Sirih Hotel, Jakarta". His research explains that the performance of employees of the marketing department of Millennium Sirih hotel, Jakarta is strongly influenced by work discipline. If the work discipline improves, it will also improve the performance of employees and vice versa, if the work discipline decreases, then the performance of its employees will also decrease [20].

3) Previous research obtained in the journal Wahid Eka Saputra and Darmanah (2019). With the title of the study "Effect of Compensation on Employee Performance on CV Meubel Jati Luhur Belitang Oku Timur". The results of his research showed that the improvement of employee performance at CV Meubel Jati Luhur Belitang OKU Timur was strongly 
influenced by compensation, one of which is the provision of welfare [21].

4) Previous research obtained in the journal Agung Surya Dwianto, Pupung Purnamasari and Tukini (2019). With the title of the study "Effect of Compensation on Employee Performance at PT Jaeil Indonesia". The results of his research explained that there is a significant influence between compensation to employee performance. This means that compensation can improve employee performance (the higher the compensation, the higher the performance) [22].

5) Previous research obtained in the journal Ali Wairooy (2017). With the title of the study "Effect of Work Discipline and Compensation on Employee Performance at PT Pertamina (Persero), Tbk. Marketing Region VII Makassar". Based on Ali Wairooy's research that work discipline and high compensation can provide improved employee performance [8].

6) Previous research obtained in the journal Junaidi and Indah Widia Lestari (2017). With the research title "The Influence of Work Discipline and Compensation on Employee Performance at The Brilliant Education Centre Probolinggo". The results of his research explained that employee performance is influenced by the existence of work discipline and compensation. But the biggest influence is the discipline of work [23].

\section{Results and Analysis}

Results and analysis of the study are derived from validity test and reliability and the classic assumption tests made up of normality, multicollinearity and Heteroscedasticity test. Thus making the data obtained worthy of use in testing the research hypothesis.

\section{1) Path Analysis}

According to data processing using the SPSS v.25 obtained correlation or linlink between work discipline and compensation of the result can be seen as follow:

Table 4

Correlation of Work Discipline Variables (X1) and Compensation (X2)

\begin{tabular}{|l|l|r|r|}
\hline \multicolumn{4}{|c|}{ Correlations } \\
\hline \multirow{2}{*}{ Work Discipline } & Pearson Correlation & Work Discipline & \multicolumn{1}{|c|}{ Compensation } \\
\cline { 2 - 4 } & Sig. (2-tailed) & 1 &, $313^{* *}$ \\
\cline { 2 - 4 } & $\mathrm{N}$ & 98 &, 002 \\
\hline \multirow{2}{*}{ Compensation } & Pearson Correlation &, $313^{* *}$ & 98 \\
\cline { 2 - 4 } & Sig. (2-tailed) &, 002 & 1 \\
\cline { 2 - 4 } & $\mathrm{N}$ & 98 & 98 \\
\hline
\end{tabular}

Source: Results of SPSS v.25 Data Processing, Researcher 2020

Based on the correlation test in table 4 above, it can be known that the correlation value between independent variables i.e. work discipline (X1) and Compensation (X2) is 0.313 . This means that work discipline and compensation have a correlation or relationship of 0.313 .

\section{2) Partial Effect of Work Discipline (X1) and Compensation (X2) on Employee Performance $(Y)$}

According to data processing using the SPSS v.25 obtained the result of coefficient of path for each variable. The results of the data processing can be seen as follows:

Table 5

Coefficient of Work Discipline Line (X1) and Compensation (X2) on Employee Performance $(Y)$

\begin{tabular}{|c|c|c|c|c|c|c|}
\hline & & & & Coefficient & & \\
\hline & & $\begin{array}{l}\text { Unstan } \\
\text { Coef }\end{array}$ & $\begin{array}{l}\text { ardized } \\
\text { cients }\end{array}$ & $\begin{array}{c}\text { Standardized } \\
\text { Coefficients }\end{array}$ & & \\
\hline & & $\mathrm{B}$ & Std. Error & Beta & $\mathrm{T}$ & Sig. \\
\hline 1 & (Constant) & 12,733 & 3,907 & & 3,259 &, 002 \\
\hline & Work Discipline & ,397 & ,078 & ,436 & 5,118 &, 000 \\
\hline & Compensation & ,324 &, 086 & ,320 & 3,761 &, 000 \\
\hline
\end{tabular}


a. Dependent Variables: Employee Performance

Source: Results of SPSS v.25 Data Processing, Researcher 2020

Table 5 above is a coefficient of work discipline line (X1) and compensation (X2) to employee performance $(\mathrm{Y})$ the value of each variable can be explained as follows:

\section{a. Coefficient of work discipline variable path to employee performance}

Can see table 5 , the coefficient of path for work discipline variable $(X 1)$ to employee performance $(\mathrm{Y})$ is 0.436 This indicates that the contribution of work discipline variable $(\mathrm{X} 1)$ to employee performance $(Y)$ is 0.436 , so obtained equation $Y=0.436 \mathrm{X} 1$. Furthermore, calculations are carried out to determine the influence of work discipline on employee performance, can be seen as follow:

Table 6

Effect of Work Discipline (X1) on Employee Performance (Y)

\begin{tabular}{|c|c|c|c|}
\hline \multirow{2}{*}{ Variable } & $\begin{array}{c}\text { Path Analysis } \\
\text { Interpretation }\end{array}$ & Calculation & $\begin{array}{c}\text { Magnitude of } \\
\text { Influence }\end{array}$ \\
\hline \multirow{2}{*}{ Work Discipline $(\mathrm{X} 1)$} & Direct influence to $\mathrm{Y}$ & 0.4362 & 0.190 \\
\cline { 2 - 4 } & $\begin{array}{l}\text { Indirect influence to } \\
\mathrm{Y}\end{array}$ & $0.436 \times 0.320 \times 0.313$ & 0.044 \\
\hline
\end{tabular}

Source: Results of SPSS v.25 Data Processing, Researcher 2020

In table 6 above shows that work discipline (X1) affects employee performance $(\mathrm{Y})$ which is $0.234=23.4 \%$.

\section{b. Compensation variable path coefficient to employee performance}

Based on table 5, the coefficient of path for compensation variable (X2) to employee performance $(Y)$ is 0.320 This indicates that the contribution of compensation variable (X2) to employee performance $(Y)$ is 0.320 , so that the equation $Y=0.320 X 2$ is obtained. Furthermore, calculations are carried out to determine the impact of compensation on employee performance, can be seen as follow:

Table 7

Effect of Compensation (X2) on Employee Performance ( $\mathrm{Y}$ )

\begin{tabular}{|c|c|c|c|}
\hline Variable & $\begin{array}{c}\text { Path Analysis } \\
\text { Interpretation }\end{array}$ & Calculation & $\begin{array}{c}\text { Magnitude of } \\
\text { Influence }\end{array}$ \\
\hline \multirow{3}{*}{ Compensation (X2) } & Direct influence to $Y$ & 0.3202 & 0.102 \\
\cline { 2 - 4 } & $\begin{array}{l}\text { Indirect influence to } \\
\text { Y }\end{array}$ & $\begin{array}{c}0.436 \times 0.320 \times 0.313 \\
\text { Total }\end{array}$ & 0.044 \\
\hline
\end{tabular}

Source: Results of SPSS v.25 Data Processing, Researcher 2020

Based on table 7 above shows that Compensation (X2) affects employee performance (Y) which is $0.146=14.6 \%$.

\section{3) Effect of Simultaneous Work Discipline and Compensation on Employee Performance}

Based on table 4, that the correlation between work discipline (X1) and compensation (X2) is 0.313 . Based on table 5 , the work discipline variable path (X1) 0.436 is higher than the compensation variable (X2) 0.320 Meaning that the work discipline (X1) has more effect on employee performance $(\mathrm{Y})$ than compensation $(\mathrm{X} 2)$. The equation of the path is as follows: $\mathrm{Y}=$ $0.436 \mathrm{X} 1+0.320 \mathrm{X} 2$. Furthermore, calculations are carried out to determine the influence of work discipline and compensation on employee performance, can be seen as follow:

Table 8

Effect of Work Discipline (X1) and Compensation (X2) on Employee Performance (Y) 


\begin{tabular}{|c|c|c|c|c|c|}
\hline \multirow{2}{*}{ Variable } & \multirow{2}{*}{$\begin{array}{c}\text { Path } \\
\text { Coefficient }\end{array}$} & \multirow{2}{*}{$\begin{array}{l}\text { Direct } \\
\text { Influence }\end{array}$} & \multicolumn{2}{|c|}{ Indirect Influence } & \multirow{2}{*}{$\begin{array}{l}\text { Subtotal } \\
\text { Influence }\end{array}$} \\
\hline & & & $\mathrm{X} 1$ & $\mathrm{X} 2$ & \\
\hline Product quality & 0.436 & 0.190 & - & 0.044 & 0.234 \\
\hline Compensation & 0.320 & 0.102 & 0.044 & - & 0.146 \\
\hline \multicolumn{5}{|c|}{ Total Simultaneous Influence } & 0.380 \\
\hline \multicolumn{5}{|c|}{ Effect of Other Variables $(£)$} & 0.620 \\
\hline
\end{tabular}

\section{Source: Results of SPSS v.25 Data Processing, Researchers 2020}

Based on table 8 above shows that the total influence caused by work discipline (X1) and compensation ( $\mathrm{X} 2$ ) on employee performance $(\mathrm{Y})$ is 0.380 or $38 \%$.

\section{Hypothesis Testing}

1) First Hypothesis

The value of $t$ count is then compared with $t$ table at the level of error $(\alpha)=5 \%$, degree of freedom $(d f)=(n-k)=98-3=95$, then it is obtained t table $=1.985 .3,400)>t$ table $(1,985)$. Then the decision is that $\mathrm{H} 0$ is rejected and $\mathrm{H} 1$ is accepted, so it can be concluded that there is a correlation between work discipline (X1) and compensation (X2).

\section{2) Second Hypothesis}

The effect of work discipline and compensation partially on employee performance with a significant level $(\alpha)=5 \%$, degree of freedom $(\mathrm{df})=(\mathrm{n}-\mathrm{k})=98-3=95$ obtained $t$ table 1,985 and and t count $(5,118)>\mathrm{t}$ table $(1,985)$ then $\mathrm{H} 0$ is rejected and $\mathrm{H} 1$ is accepted. Thus it can be concluded that work discipline (X1) and compensation (X2) partially affect employee performance ( $\mathrm{Y})$.

3) Third Hypothesis

The result of the value $f$ count $=29,054$ then compared to $f$ table significant level $(\alpha)=$ $5 \%$, degree of freedom $(\mathrm{df})=(\mathrm{n}-\mathrm{k})=98-3=95$ obtained $\mathrm{f}$ table 3.09 . Thus, it can be known that $f$ count $(29,054)>f$ table $(3,09)$ then $\mathrm{H} 0$ is rejected and $\mathrm{H} 1$ is accepted. Thus, it can be concluded that simultaneously the discipline of work (X1) and compensation (X2) affect the performance of employees $(\mathrm{Y})$.

\section{Conclusion}

Based on the results of the study, it is know that there correlation between work discipline and compensation in the Subang District Trade and Industrial Cooperative Office. Partially the discipline of work affects employee performance of $23.4 \%$ and compensation affects employee performance of $14.6 \%$. Then simultaneously (together) work discipline and compensation significantly influenced by $38 \%$ to the performance of employees of the Subang District Trade and Industrial Cooperative Office. Work discipline has a greater influence on employee performance than compensation.

Good work discipline and fair and appropriate compensation can improve employee performance to be more optimal. Thus, this research provides benefits for the Subang District Trade and Industrial Cooperative Office that work discipline and compensation have an important role in improving employee performance. So that it is better able to determine the discipline of its employees and can arrange the awarding of fair compensation.

Furthermore, researchers are expected to conduct research with other variables in order to know what affects employee performance in addition to work discipline and compensation. Furthermore, other researchers can also use the same variable but it is recommended to use different research methods in order for the research results to be updated.

\section{Reference}

[1] H. Tannady, Manajemen Sumber Daya Manusia, 1 ed. Yogyakarta: expert, 2017.

[2] J. Rudadi dan T. Hidajat, "PENGARUH DISIPLIN KERJA, MOTIVASI DAN KOMPENSASI TERHADAP KINERJA PERSONIL POLSEK SEMARANG TENGAH KOTA SEMARANG," Magisma J. IIm. Ekon. dan Bisnis, 2019, doi: 10.35829/magisma.v7i1.39.

[3] "https://nasional.sindonews.com/berita/1430422/15/membangun-sdm-wujudkan-indonesiaunggul," 2019. .

[4] "Undang-Undang Republik Indonesia Nomor 43 Tahun 1999 tentang Perubahan Atas Undang-Undang Nomor 8 Tahun 1974 tentang Pokok-pokok Kepegawaian, Bab II Pasal 
2 ayat (1)."

[5] "Peraturan Bupati Subang Nomor 57 Tahun 2016 tentang Tugas Pokok, Fungsi dan Tata Kerja Dinas Koperasi, UMKM, Perdagangan dan Perindustrian Kabupaten Subang, Bab II Pasal 2 Ayat (1)."

[6] A. Isvandiari dan L. Fuadah, "Pengaruh Kompensasi dan Disiplin Kerja Terhadap Kinerja Karyawan Bagian Produksi PG. Meritjan Kediri.," J. IIm. Bisnis dan Ekon. Asia, vol. 11, no. 2, hal. 1-8, 2017, doi: 10.32812/jibeka.v11i2.54.

[7] "Keputusan Kepala Dinas Koperasi, UMKM, Perdagangan dan Perindustrian Kabupaten Subang Nomor: 050/1249/Perencanaan tentang Indikator Kinerja Utama (IKU) Dinas Koperasi,

UMKM, Perdagangan dan Perindustrian Kabupaten Subang Tahun 2018-2023."

[8] A. Wairooy, "Pengaruh Disiplin Kerja dan Kompensasi Terhadap Kinerja Karyawan pada PT. Pertamina (Persero), Tbk. Pemasaran Region VII Makassar," J. Ad'ministrare, 2017, doi: 10.26858/ja.v4i1.3442.

[9] "Peraturan Pemerintah Nomor 30 Tahun 2019 tentang Penilaian Kinerja Pegawai Negeri Sipil, Bab I Pasal 1."

[10] I. Fahmi, PENGANTAR MANAJEMEN SUMBER DAYA MANUSIA. 2016.

[11] A. K. Poluakan, R. F. Runtuwene, dan S. A. P. Sambul, "Pengaruh Kompensasi Terhadap Kinerja Pegawai PT. PLN (Persero) UP3 Manado," J. Adm. BISNIS, 2019, doi: 10.35797/jab.9.2.2019.25114.70-77.

[12] "Peraturan Pemerintah Republik Indonesia Nomor 53 Tahun 2010 tentang Disiplin Pegawai Negeri Sipil, Bab I Pasal 1."

[13] P. Afandi, Concept \& Indicator Human Resources Management for Management Research, 1 ed. Yogyakarta: Deepublish, 2016.

[14] F. Safriandi dan W. Aginta, "Terhadap Kinerja Pegawai Pada Pt. Pelabuhan Indonesia I ( Persero ) Medan,” JURIKOM (Jurnal Ris. Komputer), hal. 443-451, 2016.

[15] Syarkani, "PENGARUH DISIPLIN KERJA TERHADAP KINERJA KARYAWAN PADA PT. PANCA KONSTRUKSI DI KABUPATEN BANJAR,” J. IIm. Ekon. Bisnis, 2017, doi: 10.35972/jieb.v3i3.136.

[16] Elbadiansyah, Manajemen Sumber Daya Manusia. 2019.

[17] Y. Sudaryo, A. Aribowo, dan N. A. Sofiati, MANAJEMEN SUMBER DAYA MANUSIA, Kompensasi Tidak Langsung dan Lingkungan Kerja Fisik. Yogyakarta: Penerbit ANDI, 2018.

[18] P. Wibowo, "Pengaruh Kompensasi Dan Motivasi Terhadap Kinerja Karyawan (Studi Kasus PT Indoraya Internasional di Yogyakarta) Fx.Pudjo Wibowo Universitas Buddhi Dharma Tangerang," J. Manaj. dan Bisnis, vol. X, hal. 173-189, 2018.

[19] J. N. Liyas dan R. Primadi, "Pengaruh disiplin kerja terhadap kinerja karyawan pada bank perkreditan rakyat," Al Masraf J. Lemb. Keuang. dan Perbank., 2017.

[20] R. A. Hajrina, I. Mariam, dan M. Wijiyanty, "Pengaruh Disiplin Kerja Terhadap Kinerja Karyawan Bagian Marketing Pada Hotel Millennium Sirih , Jakarta," Ekon. dan Bisnis, 2016.

[21] W. E. Saputra dan Darmanah, "PENGARUH KOMPENSASI TERHADAP KINERJA KARYAWAN PADA CV. MEUBEL JATI LUHUR BELITANG OKU TIMUR,” J. Aktual, 2019, doi: 10.47232/aktual.v17i1.29.

[22] A. S. Dwianto, P. Purnamasari, dan T. Tukini, "Pengaruh Kompensasi Terhadap Kinerja Karyawan Pada PT. JAEIL INDONESIA,” Jesya (Jurnal Ekon. Ekon. Syariah), vol. 2, no. 2, hal. 209-223, 2019, doi: 10.36778/jesya.v2i2.74.

[23] Junaidi dan I. W. Lestari, "Kinerja Karyawan Pada Lembaga Pendidikan Brilliant Education Center Probolinggo.," J. Ecobuss, vol. 5, no. 1, hal. 2337-9340, 2017. 